\title{
Antimitotic activity of EA21b mammary-carcinoma extract
}

\author{
Mirta Alicia Flamini ${ }^{1,2}$, Norma Viviana GonzÁlez ${ }^{1,3}$ \& Claudio Gustavo Barbeito ${ }^{1,2,4 *}$ \\ ${ }^{1}$ Cátedra de Histología y Embriología, Facultad de Ciencias Veterinarias, Universidad Nacional de La Plata, 60 y 118 , CP \\ 1900, La Plata,Buenos Aires, Argentina; e-mail: barbeito@fcv.unlp.edu.ar \\ ${ }^{2}$ Instituto de Patología, Facultad de Ciencias Veterinarias, Universidad Nacional de La Plata, La Plata, Buenos Aires, \\ Argentina \\ ${ }^{3}$ Cátedra de Histología y Embriología Animal, Facultad de Ciencias Naturales y Museo, Universidad Nacional de La Plata, \\ La Plata, Buenos Aires, Argentina \\ ${ }^{4}$ CONICET (National Scientific Research Council, Argentina)
}

\begin{abstract}
Many tumors produce factors that affect cell-cycle and cell proliferation. In the present study we have analyzed the effect of a mammary-tumor extract injection on the mitotic activity of several organs in young male C3H/S mice previously standardized for circadian periodicity. One-half of the animals received an intraperitoneal EA21b tumor extract dose at 16:00 h, while the other half received saline. Animals were sacrificed on the following day at 08:00, 12:00 or 16:00 $\mathrm{h}$, $4 \mathrm{~h}$ after receiving an injection of colchicine by the same route. Samples of duodenum, kidney, liver, and submaxillary gland were excised and processed for hematoxylin-eosin staining. Mitotic indices, expressed as the number of colchicine-arrested metaphases per 1,000 nuclei, were assessed in convoluted tubule epithelium, duodenal crypt enterocytes, hepatocytes and submaxillary gland ductal and acinar sialocytes. All values were expressed as mean \pm SEM. Statistical analyses were performed by ANOVA, Bonferroni and Student's t-tests. In contrast to the mitotic indices reductions observed in renal convoluted tubules cells and duodenal crypt enterocytes, neither the submaxillary gland nor the liver were found to contain cell types whose mitotic activity was affected by the tumor extract. We conclude that EA21b mammary carcinoma contains one or more factors that inhibit the proliferation of selected populations of normal cells.
\end{abstract}

Key words: tumor extracts; cell proliferation; growth factors; kidney; duodenum.

\section{Introduction}

Neoplastic tissues have long been investigated as a potential source of cell-growth regulators (Malmgren 1956; Malmgren \& Mills 1961; Badrán et al. 1985a; Moreno et al. 1992). Research has been aimed mainly at the characterization of tumor cells' alterations that render them insensitive to mechanisms regulating cell proliferation (Mackay et al. 1995; Huitfeldt et al. 1996) and cell death (Fantin \& Leder 2006). The pioneering work by Malmgren (1956) demonstrated the presence of a mitogen extracted from a mammary carcinoma with specific activity in adult mouse liver (Malmgren 1956; Malmgren \& Mills 1961). A similar line of research carried out in our laboratory in murine tumors allowed us to report that EA34 mammary carcinoma has a growthpromoting activity that is specific for prepuberal mouse hepatocytes (Moreno et al. 1992; Flamini et al. 1996).

These observations led us to explore the action of EA21b mammary-carcinoma extracts on the proliferation of various selected cell populations in young mice from liver, kidney, duodenum and submaxillary gland, employing the mitotic arrest technique. Results obtained from those experiments are reported and discussed in this communication.

\section{Material and methods}

\section{Animals}

Thirty nine male four-week old $\mathrm{C} 3 \mathrm{H} / \mathrm{S}$ inbred mice from the Embryology, Biology and Histology Institute (School of Medical Sciences, National University of La Plata) were used. Animals weighed $15.1 \pm 0.26 \mathrm{~g}$ at the time of sacrifice. Mice were housed in individual cages under standard conditions for circadian periodicity analysis in a temperaturecontrolled room at $22 \pm 2 \mathrm{C}$ with a 12-h alternating lightdark cycle beginning at 06:00 h. Tap water and pellet food were provided ad libitum. Housing, feeding and handling conditions secured animal welfare according to the specific international laws.

\section{Tumor}

Subline b from the EA21 transplantable murine mammary carcinoma was employed. The abbreviation refers to the following: E, espontáneo (spontaneous); A, originating in the $\mathrm{C} 3 \mathrm{H} /$ Avy strain of mice; 21, the twenty-first tumor line arising from the Embryology, Biology and Histology Institute laboratory stock. The tumor strain was maintained by serial subcutaneous transplants into female adult $\mathrm{C} 3 \mathrm{H} / \mathrm{S}$-strain mice. EA21 is a highly undifferentiated and invasive tumor; its major architectural pattern includes rounded tumoral masses, with several layers of dark-stained epithelial cells. Cancerous cells also present a small cytoplasm and a big hyperchromatic nucleus. A reduced lumen may be observed

\footnotetext{
* Corresponding author
} 

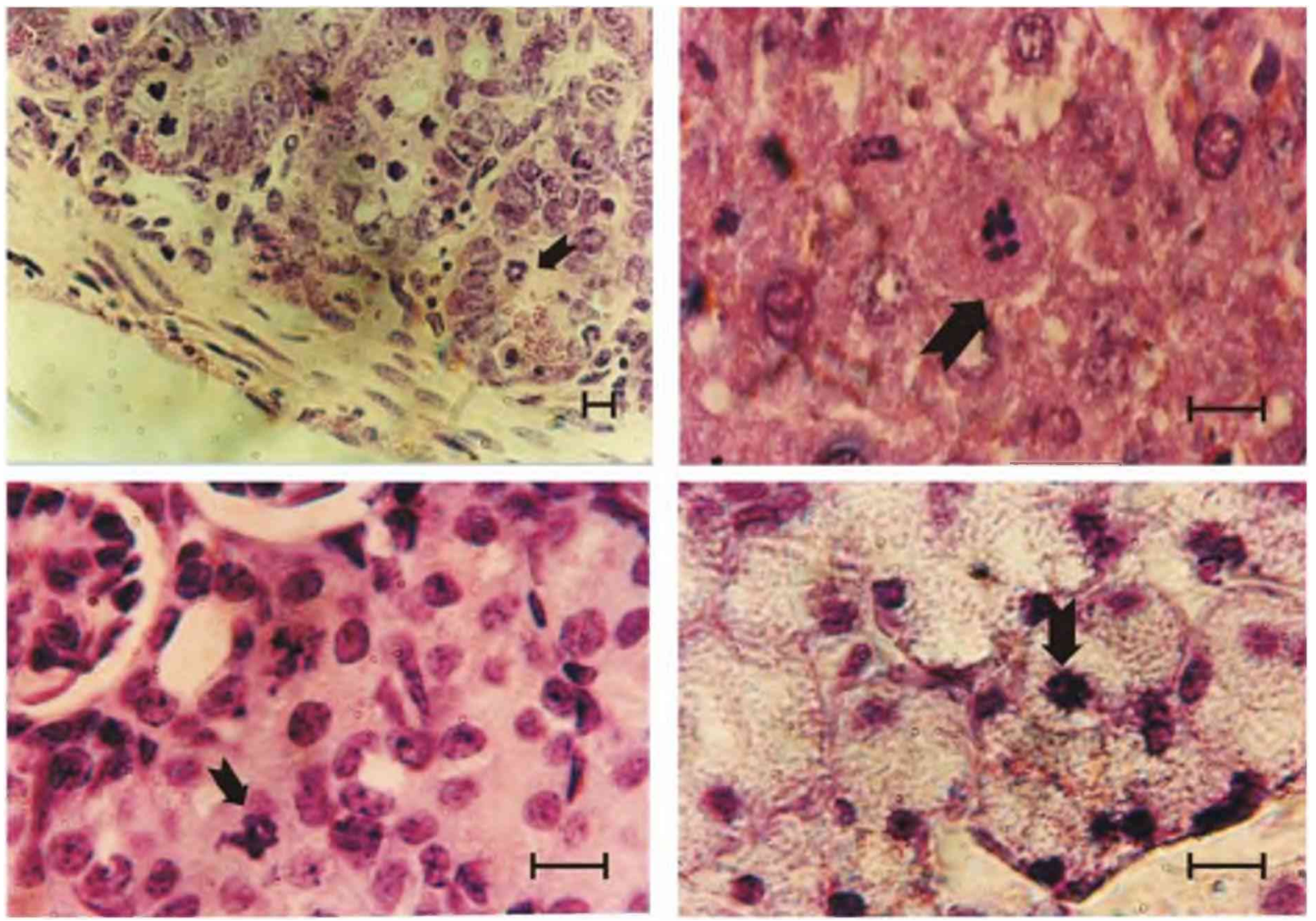

Fig. 1. Arrows point colchicine metaphases in duodenal crypt enterocytes (upper left image; 40×), hepatocytes (upper right image; $100 \times$ ), convoluted tubules epithelia (bottom left image; $100 \times$ ), and acinar sialocytes (bottom right image; $100 \times$ ). Bar scale: $10 \mu \mathrm{m}$. Hematoxiline-eosine.

in tumoral masses. The carcinoma kills $50 \%$ of the bearers within five weeks.

\section{Tumor extract preparation}

Tumors from three donors were pooled for extract preparation. Small pieces showing neither necrosis nor hemorrhage were teased away and placed for homogenization in a PotterDual tissue grinder at $0 \mathrm{C}$. The tissue was disrupted in distilled water $(1: 9, \mathrm{w} / \mathrm{v})$ at a rate of 10 strokes within $\sim 30 \mathrm{~s}$ and the resulting homogenate centrifuged at 4,000 rpm and $4 \mathrm{C}$ for $20 \mathrm{~min}$. The supernatant was immediately injected.

\section{Experimental design}

Recipient animals were injected intraperitoneally with either tumor extract $(2 \mathrm{mg} / 0.01 \mathrm{~mL} / \mathrm{g}$ body weight) or 0.01 $\mathrm{mL}$ saline/g body weight at 16:00 h. The time of day for this procedure was selected according to previous work for it corresponds to the end of $\mathrm{G}_{1}$ phase for the majority of cells destined to enter mitosis at 12:00 h. Mice were sacrificed by decapitation and exanguination at 08:00/16, 12:00/20, and $16: 00 / 24$ (time of day/h post injection) $(n=6-7)$. Each lot of animals received a $2 \mu \mathrm{g} / \mathrm{g}$ body weight colchicine intraperitoneal injection $4 \mathrm{~h}$ before sacrifice. Specific times for sacrifice were chosen due to the knowledge that mitotic activity highest values for most cell populations under study occur at/around 12:00 $\mathrm{h}$ in these diurnally-synchronized mice (Barbeito et al. 2002b; Bjarnason \& Jordan 2002).

\section{Mitotic activity measurement}

Liver, kidney, duodenum, and submaxillary gland samples were fixed in $10 \%(\mathrm{v} / \mathrm{v})$ buffered formalin and processed for histology. The following cell-types were monitored: kidney convoluted tubule cells, duodenal crypt enterocytes, hepatocytes and ductal and acinar sialocytes. The scoring of colchicine-arrested metaphases on 140 microscopic fields and the total number of cell nuclei within every tenth field was performed for liver, kidney and submaxillary gland tissue samples at a $1,500 \mathrm{x}$ magnification. The monitoring in duodenal samples comprised only longitudinally cut crypt sections divided into three regions: cell tiers $1-4,5-12$, and 13-20, proceeding from crypt bottom to top, respectively. All slides were encoded and the scoring was performed by MAF and NVG blinded to experimental conditions. Mitotic indices were expressed as the number of colchicine-arrested metaphases per 1,000 nuclei.

\section{Statistical analysis}

The mean value \pm SEM of the mitotic indices were calculated for each cell population monitored. Comparisons between mean values for each lot and time-points were performed by ANOVA test. Bonferroni was used as post-test. Student's t-test was employed to analyze mean values for each treatment.

\section{Results}

The colchicine effect was detected in all cell populations under study by the observation of cell-arrested metaphases in tissue sections (Fig. 1).

The results found in our survey on selected cell populations are presented in Tables $1-5$ as follows: Tab. 1 - convoluted-tubule cells; Tab. 2 - duodenal 
Table 1. Mitotic activity of kidney convoluted-tubule cells. ${ }^{a}$

\begin{tabular}{ccccccccc}
\hline \multirow{2}{*}{$\begin{array}{c}\text { Time of day } \\
\text { h post injection }\end{array}$} & \multicolumn{3}{c}{ Saline } & & \multicolumn{4}{c}{ EA21b extract } \\
\cline { 2 - 3 } \cline { 6 - 8 } & $X \pm \mathrm{SE}$ & $n$ & & $X$ & $\pm \mathrm{SE}$ & $n$ & $p$ \\
\hline $08: 00 / 16$ & $4.56 \pm 0.83$ & 7 & $3.78 \pm 0.44$ & 6 & $\mathrm{NS}$ \\
$12: 00 / 20$ & $4.68 \pm 0.82$ & 7 & $1.55 \pm 0.16$ & 7 & $\mathrm{NS}$ \\
$16: 00 / 24$ & $2.32 \pm 0.43$ & 6 & $1.10 \pm 0.25$ & 6 & $\mathrm{NS}$ \\
$08+12+16$ & $3.85 \pm 0.47$ & 20 & $2.14 \pm 0.31$ & 19 & $<0.005$ \\
\hline
\end{tabular}

a $X$ : mean; SE: standard error; $n$ : number of animals; $p$ : statistical signification; NS: not significant.

crypt enterocytes; Tab. 3 - hepatocytes; Tab. 4 - ductal syalocites; and Tab. 5 - acinar sialocytes.

A significant mitotic activity decrease in both renal convoluted tubules cells (Tab. 1) and duodenal-crypt enterocytes from tumor-extract injected mice (Tab. 2) over saline administered animals was found.

The renal convoluted cells exhibited a significant cell-proliferation diminution at 12:00/20 $(p<0.01)$ (Tab. 1). The mitotic index reduction observed in the duodenal crypts enterocytes at cell tiers 1-20 was restricted to a mitotic index peak at 12:00/20 $(p<0.05)$ and to the average mitotic value of all time-points assessed $(p<0.05)$ (Tab. 2). The crypt zonal study detected that the decrease in mitotic activity was localized in cell tiers 13-20. Moreover, both treatments rendered similar mitotic activity variations; cell tiers 5-12 showed the highest mitotic index whereas cell tiers 1-4 exhibited the minimal mitotic values.

In contrast to the mitotic indices changes observed in renal convoluted tubules cells and duodenal crypt enterocytes, neither the submaxillary gland nor the liver
Table 3. Mitotic activity of hepatocytes. ${ }^{a}$

\begin{tabular}{cccccccc}
\hline \multirow{2}{*}{$\begin{array}{c}\text { Time of day } \\
\text { h post injection }\end{array}$} & \multicolumn{3}{c}{ Saline } & & \multicolumn{3}{c}{ EA21b extract } \\
\cline { 2 - 3 } \cline { 6 - 7 } & $X \pm \mathrm{SE}$ & $n$ & & $X \pm \mathrm{SE}$ & $n$ & $p$ \\
\hline $08: 00 / 16$ & $0.53 \pm 0.23$ & 7 & $0.52 \pm 0.20$ & 6 & $\mathrm{NS}$ \\
$12: 00 / 20$ & $1.28 \pm 0.33$ & 7 & $0.62 \pm 0.11$ & 7 & $\mathrm{NS}$ \\
$16: 00 / 24$ & $0.41 \pm 0.05$ & 6 & $0.29 \pm 0.10$ & 6 & $\mathrm{NS}$ \\
$08+12+16$ & $0.74 \pm 0.11$ & 20 & $0.48 \pm 0.08$ & 19 & $\mathrm{NS}$ \\
\hline
\end{tabular}

${ }^{a} X$ : mean; $\mathrm{SE}$ : standard error; $n$ : number of animals; $p$ : statistical signification; NS: not significant.

Table 4. Mitotic activity of ductal sialocytes. ${ }^{a}$

\begin{tabular}{cccccccc}
\hline \multirow{2}{*}{$\begin{array}{c}\text { Time of day } \\
\text { h post injection }\end{array}$} & \multicolumn{3}{c}{ Saline } & & \multicolumn{3}{c}{ EA21b extract } \\
\cline { 2 - 3 } \cline { 6 - 8 } & $X \pm \mathrm{SE}$ & $n$ & & $X \pm \mathrm{SE}$ & $n$ & $p$ \\
\hline $08: 00 / 16$ & $6.67 \pm 1.40$ & 7 & $6.85 \pm 1.76$ & 6 & $\mathrm{NS}$ \\
$12: 00 / 20$ & $6.69 \pm 0.51$ & 7 & $5.62 \pm 0.59$ & 7 & $\mathrm{NS}$ \\
$16: 00 / 24$ & $3.15 \pm 0.44$ & 6 & $2.00 \pm 0.36$ & 6 & $\mathrm{NS}$ \\
$08+12+16$ & $5.50 \pm 0.63$ & 20 & $4.82 \pm 0.77$ & 19 & $\mathrm{NS}$ \\
\hline
\end{tabular}

a $X$ : mean; SE: standard error; $n$ : number of animals; $p$ : statistical signification; NS: not significant.

were found to contain cell types whose mitotic activity was affected by the tumor extract (Tabs 3-5).

\section{Discussion}

Our results showed that two out of the eight cell populations under study exhibited a significant mitotic ac-

Table 2. Mitotic activity of duodenal crypt enterocytes. ${ }^{a}$

\begin{tabular}{|c|c|c|c|c|c|c|c|c|}
\hline \multirow{2}{*}{ Tiers } & \multirow{2}{*}{$\begin{array}{c}\text { Time of day/ } \\
\mathrm{h} \text { post injection }\end{array}$} & \multicolumn{3}{|c|}{ Saline } & \multicolumn{4}{|c|}{ Tumor extract } \\
\hline & & $X \pm$ & $\mathrm{SE}$ & $n$ & $X=$ & $\mathrm{SE}$ & $n$ & $p$ \\
\hline \multirow[t]{4}{*}{ a } & $08: 00 / 16$ & $52.68 \pm$ & 12.78 & 7 & $41.67=$ & 5.74 & 6 & NS \\
\hline & $12: 00 / 20$ & $64.29 \pm$ & 4.66 & 7 & $48.21=$ & 6.20 & 7 & NS \\
\hline & $16: 00 / 24$ & $44.79 \pm$ & 15.42 & 6 & $61.46=$ & 8.44 & 6 & NS \\
\hline & $08+12+16$ & $54.38 \pm$ & 6.52 & 20 & $50.33=$ & 4.17 & 19 & NS \\
\hline \multirow[t]{4}{*}{$\mathrm{b}$} & $08: 00 / 16$ & $169.20 \pm$ & 25.18 & 7 & $127.61=$ & 15.80 & 6 & NS \\
\hline & $12: 00 / 20$ & $192.41 \pm$ & 14.78 & 7 & $149.56=$ & 11.99 & 7 & NS \\
\hline & $16: 00 / 24$ & $161.98 \pm$ & 15.38 & 6 & $194.80=$ & 20.97 & 6 & NS \\
\hline & $08+12+16$ & $175.16 \pm$ & 11.03 & 20 & $156.91=$ & 10.93 & 19 & NS \\
\hline \multirow[t]{4}{*}{ c } & $08: 00 / 16$ & $108.04 \pm$ & 16.06 & 7 & $58.34=$ & 9.93 & 6 & NS \\
\hline & $12: 00 / 20$ & $134.38 \pm$ & 12.21 & 7 & $79.02=$ & 15.79 & 7 & NS \\
\hline & $16: 00 / 24$ & $95.84 \pm$ & 8.93 & 6 & $91.67=$ & 14.67 & 6 & NS \\
\hline & $08+12+16$ & $113.60 \pm$ & 8.05 & 20 & $76.48=$ & 8.25 & 19 & $<0.003$ \\
\hline \multirow[t]{4}{*}{$d$} & $08: 00 / 16$ & $121.43 \pm$ & 17.90 & 7 & $82.71=$ & 9.74 & 6 & NS \\
\hline & $12: 00 / 20$ & $143.57 \pm$ & 9.88 & 7 & $101.07=$ & 10.65 & 7 & $<0.05$ \\
\hline & $16: 00 / 24$ & $112.08 \pm$ & 9.18 & 6 & $126.88=$ & 11.79 & 6 & NS \\
\hline & $08+12+16$ & $126.37 \pm$ & 7.87 & 20 & $103.42=$ & 7.19 & 19 & $<0.04$ \\
\hline
\end{tabular}

a $X$ : mean; SE: standard error; $n$ : number of animals; $p$ : statistical signification; NS: not significant; a: tiers $1-4$; b: tiers $5-12$; c: tiers 13-20; d: tiers $1-20$. 
Table 5. Mitotic activity of acinar sialocytes. ${ }^{a}$

\begin{tabular}{cccccccc}
\hline $\begin{array}{c}\text { Time of day } \\
\text { h post injection }\end{array}$ & \multicolumn{3}{c}{ Saline } & & \multicolumn{3}{c}{ EA21b extract } \\
\cline { 2 - 3 } \cline { 6 - 8 } & $X \pm \mathrm{SE}$ & $n$ & & $X \pm \mathrm{SE}$ & $n$ & $p$ \\
\hline $08: 00 / 16$ & $1.80 \pm 0.32$ & 7 & $2.81 \pm 0.64$ & 6 & $\mathrm{NS}$ \\
$12: 00 / 20$ & $1.42 \pm 0.66$ & 7 & $1.36 \pm 0.29$ & 7 & $\mathrm{NS}$ \\
$16: 00 / 24$ & $0.49 \pm 0.09$ & 6 & $0.55 \pm 0.20$ & 6 & $\mathrm{NS}$ \\
$08+12+16$ & $1.24 \pm 0.27$ & 20 & $1.57 \pm 0.32$ & 19 & $\mathrm{NS}$ \\
\hline
\end{tabular}

a $X$ : mean; $\mathrm{SE}$ : standard error; $n$ : number of animals; $p$ : statistical signification; NS: not significant.

tivity reduction. The results obtained for renal convoluted tubules cells and duodenal crypt enterocytes would be consistent with the following plausible explanations: (a) EA21b mammary carcinoma extracts contain factor/s that is at least potentially inhibitory to cell-cycle progression; (b) both renal convoluted tubules and duodenal-crypt epithelial cells respond to these putative growth inhibitors, thus suggesting that these cell populations constitute natural target cells and as such, probably possess specific receptors; and (c) liver and submaxillary glands cell populations under study most probably lack receptors to factors contained in the assessed tumor extract.

Our findings are in marked contrast to the mitotic activity enhancement reported for adult mice (Malmgren 1956; Malmgren \& Mills 1961). A similar stimulation was found by our group for 28-day old mice after the administration of an extract from EA34, a different neoplasia. This is a differentiated mammary carcinoma spontaneously originated in the $\mathrm{C} 3 \mathrm{H} / \mathrm{S}$ strain (Moreno et al. 1992). No such proliferation increase was observed in intact or regenerating liver when a similar protocol was employed in adult mice (Flamini et al. 1996); these findings suggest that the extract's effect on mitosis may be age-dependent.

On the other hand, extract preparations from different tumor lines have likewise been found to act negatively on the cell-cycle progression in several cell populations. For example extracts from ES2 (Badrán et al. 1985b; Echave Llanos et al. 1986; Errecalde \& Echave Llanos 1993, Inda et al. 1997) and SS1K hepatocellular carcinomas (Badrán et al. 1985a; Ottino \& Echave Llanos 1990) have been particularly effective in the inhibition of cell-cycle progression. These results clearly show that the effects on cell-cycle vary significantly according to the type of tumor employed to prepare the extract.

The EA21 tumor grafted in the same mice strain has a mitogenic effect on enterocytes (Barbeito et al. 2002a) as well as on renocytes (Catalano et al. 1996). These findings suggest that the chronic effect caused by a grafted tumor may result opposed to the acute action exerted by the same neoplasia extract injection. However, the stimulating effect promoted by EA21 tumor graft has not been found in other cell populations, such as pars intermedia cells (Surur et al. 2005).
In coincidence with the present investigation, differences among findings in tumor-bearing animals and in tumor extract-injected mice have also been demonstrated for the SS1K hepatocellular carcinoma (Barbeito et al. 1997). In this regard, the wide spectrum of cell types exhibiting either growth stimulatory or inhibitory responses to these different malignant lines extracts are valuable data that emphasize the need for a precise characterization on the nature and specificity of the tumor-associated biological activity and host-tissue sensitivity relationships.

Considering the growth-retarding agents described, the transforming growth factor $\beta($ TGF $\beta$ ) family constitutes the most relevant group of substances that have been shown to affect kidney convoluted tubules cells and intestinal crypts epithelium (Massague 1990; Jiang et al. 2003). Nevertheless, these peptides inhibit hepatocytic proliferation as well (Masuhara et al. 1996; Breitkopf et al. 2006), a response which we did not observe in the present assays. Growth factors that usually promote cell proliferation may also act as inhibitors under certain experimental conditions as revealed by Geimer $\&$ Bade (1991). In the experiments reported here, absence of adverse histological or cytological changes in tumor extract-treated animals would suggest that the action exerted did not occur as a result of non-specific toxicity. For this reason, the active components detected in the EA21b tumor extracts may well not correspond to any of the growth factors previously mentioned. Yet it is possible that the hepatic response was either severely mitigated or altogether prevented by some condition, such as animal age (Opleta et al. 1987) rendering not comparable observations between our data and those reported by the above-mentioned authors.

Until few years ago, the majority of the substances regulating the cell-cycle as external signals were acknowledged to act on the $\mathrm{G}_{1}-\mathrm{S}$ phase transition, especially on cyclin D and cyclin-dependent kinases (CDKs) - cyclins complexes. More recently, regulatory substances affecting gene expression and their products? activity on other cell-cycle phases have been found. Some of them include short peptides, e.g. the synthetic hexapeptide termed NBI1, reported by Canela et al. (2006). NBI1 binds to a surface pocket in cyclin A and inhibits the catalytic activity of the complex cyclindependent kinase 2-cyclin A required for the cell to progress through $\mathrm{S}$ phase. However, no natural peptides exhibiting a comparable functional role have been isolated from normal or neoplastic tissues. Some growth factors well known for their activity, such as tumor necrosis factor $\alpha(\mathrm{TNF} \alpha)$, can inhibit cyclin A in certain experimental conditions (Wen et al. 2004). Strikingly, TNF $\alpha$ was previously reported as a stimulating agent for the hepatocytic proliferation in regenerating liver (Fausto 2000). These facts lead to a clear demonstration that the response displayed on cell-cycle to different substances may vary in relation to the cell population and the experimental design. In this way, it can be hypothesized the possible presence in the EA21 tu- 
mor extract of an antimitotic agent, different than the TGF $\beta$ family. The resolution of this issue must wait for a further characterization of the nature of the mitotic activity regulating factor/s in the EA21b tumor.

\section{Acknowledgements}

This work was supported with grants from the National University of La Plata. Thanks are due to Mr. Ruben Mario and Ms. Paula Dumont for their technical assistance. Animals were provided by the Embryology, Biology and Histology Institute, School of Medical Sciences, National University of La Plata.

\section{References}

Badrán A.F., Moreno F.R. \& Echave Llanos J.M. 1985a. Effect of tumour extracts on liver growth: hepatocarcinomas $\mathrm{SS} 1 \mathrm{H}$ and SS1K. Com. Biol. 2: 143-149.

Badrán A.F., Moreno F.R. \& Echave Llanos J.M. 1985b. Development of the effect of an indifferentiated tumour extract on sinusoidal litoral cells of young growing liver. Microsc. Electron. Biol. Celular 9: 13-21.

Barbeito C.G., Albarenque S.M., Reyna J.C., Flamini M.A., Andrés Laube P.F. \& Badrán A.F. 2002a. Mitotic activity of the duodenal crypt enterocytes in mice transplanted with EA21a mammary carcinoma. Cell Biol. Int. 26: 123-125.

Barbeito C.G., Flamini M.A., García M.N., Andrés Laube P.F., Andrini L.B. \& Badrán A.F. 2002b. Development of compensatory hepatic hyperplasia in mice carrying the hepatocellular carcinoma ES12a. J. Clin. Exp. Cancer Res. 21: 397-400.

Barbeito C.G., Garcia M.N., Savignone C.A., Catalano V.A., Badrán A.F., Flamini M.A \& Moreno F.R. 1997. Actividad mitótica de los epitelios de epidermis, lengua, túbulos contorneados renales y conductos de la glándula submaxilar del ratón portador del tumor SS1K. Ciencias Morfológicas 3: 918.

Bjarnason G.A. \& Jordan R. 2002. Rhythms in human gastrointestinal mucosa and skin. Chronobiol. Int. 19: 129 $\frac{140 .}{14}$

Breitkopf K., Godoy P., Ciuclan L., Singer M.V. \& Dooley, S. 2006. TGF- $\beta /$ Smad signaling in the injured liver. Z. Gastroenterol. 44: $57-66$.

Canela N., Orases M., Fucho R., Mateo F., Gutierrez R., PinedaLucena A., Bachs O. \& Perez-Paya E. 2006. Identification of an hexapeptide that binds to a surface pocket in cyclin $A$ and inhibits the catalytic activity of the complex cyclin-dependent kinase 2-cyclin A. J. Biol. Chem. 281: 35942-35953.

Catalano V.A., Barbeito C.G., Moreno F.R. \& Badrán A.F. 1996. Análisis de la actividad mitótica de la corteza renal en ratones portadores del tumor EA21a. Ciencias Morfológicas 2: 3-14.

Echave Llanos J.M., Badrán A.F. \& Moreno F.R. 1986. Inhibiting effect of a hepatoma extract on the mitotic rate of regenating liver. Virchows Arch. (Cell Pathol.) 51: 17 -27 .
Errecalde A.L. \& Echave Llanos J.M. 1993. Effect of ES2 tumor extract and plasma of tumor bearing animals on the mitotic activity of enterocytes of young mice. J. Exp. Clin. Cancer Res. 12: $75-79$.

Fausto N. 2000. Liver regeneration. J Hepatol. 32 (Suppl 1): $19-31$.

Flamini M.A., González N.V., Barbeito C.G., Badrán A.F. \& Moreno F.R. 1996. Study on a tumoral factors stimulant of hepatocyte mitosis. Analecta Veterinaria 16: 14-16.

Geimer P. \& Bade E.G. 1991. The epidermal growth factorinduced migration of rat liver epithelial cells is associated with a transient inhibition of DNA synthesis. J. Cell. Sci. 100: $349-355$.

Huitfeldt H., Skarpen E., Lindeman B., Becher R., Thrane V. \& Schwarze P.J. 1996. Differential distribution of met and epidermal growth factor receptor in normal and carcinogentreated rat liver. Histochem. Cytochem. 44: 227-233.

Inda A.M., García A.L., Errecalde A.L. \& Badrán A.F. 1997. Effect of tissue and plasma factors on kidney proliferation. Biocell 2: 13-18.

Jiang B., Zhang J.S., Du J., Urrutia R. \& Barnard J. 2003. Growth inhibitory signalling by TGF $\beta$ is blocked in Rastransformed intestinal epithelial cells at a post-receptor locus. Cell. Signal. 15: 699-708.

Malmgren R.A. 1956. Observations on a liver stimulant present in tumour tissues. Cancer Res. 16: 232-236.

Malmgren R.A. \& Mills W. 1961. Studies of properties of the liver mitotic stimulant (LMS) in mouse tumor tissue. J. Nat. Cancer Inst. 26: 525-532.

Massague J. 1990. The transforming growth factor $\beta$ family. Annu. Rev. Cell. Biol. 6: 597-641.

Masuhara M., Yasunaga M., Tanigawa K., Tamuta F., Yamashita S., Sakaida I. \& Okita K. 1996. Expression of hepatocyte growth factor, transforming growth factor $\alpha$ and transforming growth factor $\beta 1$ messenger RNA in various human liver diseases and correlation with hepatocyte proliferation. Hepatology 24: 323-329.

Moreno F.R., Badrán A.F. \& Flamini M.A. 1992. Effect of tumor extracts on the liver proliferation in young mice. Com. Biol. 10: 336 .

Opleta K., O'Loughlin E.V., Shaffer E.A., Hayden J., Hollemberg M. \& Gall D.G. 1987. Effect of epidermal growth factor on growth and postnatal development of the rabbit liver. Am. J. Physiol. 253: 622-625.

Ottino A. \& Echave Llanos J.M. 1990. Efecto inhibidor del extracto del hepatocarcinoma transplantado SS1K y del plasma de los portadores sobre la actividad mitótica de los hepatocitos y células litorales del hígado de ratón. Patología 28: $155-160$.

Surur J.M., Catalano V.A., Flamini M.A. \& Barbeito C.G. 2005. Effects of presence of tumors on the daily mitotic activity of mouse pars intermedia Cell Biol. Int. 29: 173-175.

Wen H.S., Yin Y., Broussard S.R., McCusker R.H., Freund G.G., Dantzeri, R. \& Kelley K.W. 2004. Tumor necrosis factor $\alpha$ inhibits cyclin A expression and retinoblastoma hyperphosphorylation triggered by insulin-like growth factor-I induction of new E2F-1 synthesis. J. Biol. Chem. 279: 7435-7446.

Received August 23, 2006 Accepted January 31, 2007 